\title{
Tese og anti-tese om begrebet karakter
}

At ordet 'karakter' og beslægtede termer (som f.eks. person, figur, skikkelse) i vidt omfang bliver brugt på mange forskellige og modstridende måder, kunne give anledning til den konklusion, at der ikke kan uddrages noget entydigt koncept herfor - ingen egenskab eller gruppe af egenskaber, der konstituerer en essens af unik naturlig eller kulturel art. En sådan konklusion kan yderligere bekræftes med henvisning til det kaos og den uegalitet, som kendetegner forskellige teoretikeres forsøg på at belyse begrebet. Læg endvidere her mærke til forskelligheden i de kontekster, i hvilke disse begreber anvendes: filosoffer plejer at betragte karakterbegrebet i forhold til metafysiske og moralske overvejelser om personlig identitet, ansvar, jeg'ets selvstændighed osv.; psykologer forbinder karakter med skemaer udformet til klassifikation af personlighedsstruktur eller systemer af individuelle træk og dispositioner; mens litterære teoretikere ofte (men ikke altid) tænker på karaktererne primært som elementer i eller følger af bestemte typer af litterære og andre diskurser. Hvad har disse forskellige opfattelser af karakter til fælles? Bevisbyrden er selvsagt placeret på skuldrene af den person, der påstår, at der kan henvises til ét distinkt element på tværs af så forskellige anvendelser af ordet »karakter». Indtil denne byrde er blevet løftet, må vores konklusion være, at karakterer bedst refererer til, hvad Locke kaldte »nominal essences«, hvormed der menes typer eller kategorier defineret ved hjælp af nogle tilfældigt stipulerede grupper af karaktertræk.

Spørgsmålet er så, om denne konklusion - at »karakter« kun refererer til nominelle enheder - også gør sig gældende for den mere begrænsede anvendelse af begrebet indenfor litteraturteori, kulturkritik og æstetik; det vil sige for betegnelsen littercere (dramatiske, filmiske etc.) karakterer? Er der selv inden for denne mere specialiserede, disciplinerede kontekst ingen konsensus? Med henvisning til dette spørgsmål kan de relevante kontrastive teser opridses som følger:

Tese: Korrekt anvendt henviser begrebet »litterær karakter" til et specifikt aspekt eller en specifik egenskab ved litterære værker. 
Antitese: Ordet »karakter« refererer ikke til én bestemt type litterær enhed, men er en betegnelse for typer, som er konstrueret eller projiceret på uegale måder af forskelligt motiverede teoretiske og kritiske projekter.

Et umiddelbart og tilsyneladende afgørende bevis, der støtter antitesen, kan tage form som en undersøgelse af faglitteraturen med dens mange overbevisende, men dog inkompatible forslag til, hvad der ultimativt bliver en stipulering af kun nogle af begrebets betydninger. ${ }^{1}$ Alligevel vil en fortaler for tesen hertil kunne hævde, at der ikke desto mindre findes et kerneforhold, der må opfyldes af alle adækvate, konkurrerende forslag til Karakterens Natur: Selvom ingen af de modstridende forslag rent faktisk med held har identificeret essensen af karakteren, forstået som en evigt gældende type (en kategori af metafysisk substans eller naturlig art), er det dog stadig sådan, at visse, minimale egenskaber ved karakteren synes at være fælles og bliver taget for givet inden for kritiske diskurser, som på et andet niveau, tydeligvis er meget divergerende. Groft sagt kan en fortaler for tesen forsvare et minimalistisk karakterkoncept ved at hævde, at de divergenser og konceptuelle inkonsistenser, som fortaleren for antitesen korrekt identificerede, har at gøre med begreber af en mere selvstændig og normativ vægtet forskellighed, som minimalisten ikke nødvendigvis accepterer som gyldige.

Fortaleren for denne minimalistiske eller 'deflatoriske' måde at tænke på må dog eksplicit identificere de formodede (latente) omstændigheder og vise, at den foreslåede opfattelse af karakter faktisk er tilstrækkelig minimal til at modstå modsigelser og modeksempler. I det følgende vil jeg lægge ud med at opstille et sådant forslag. I anden del undersøger jeg kort nogle mulige indvendinger, og i tredje del giver jeg et fragment af den dialektik

1. En sådan undersøgelse kan starte med Hélène Cixous: „The Character of »Character««, New Literary History 5 (1975), pp. 383-402; Baruch Hochman: Character in Literature, Ithaca \& London 1985; James Phelan: Reading People, Reading Plots. Character, Progression, and the Interpretation of Narrative, Chicago 1989; Richard J. Gerrig og David W. Allbritton: "The Construction of Literary Character. A View from Cognitive Psychology ", Style 24 (1990), pp. 380-389; og de følgende essays af Uri Margolin: „Characterization in Narrative. Some Theoretical Prolegomena", Neophilologus 67 (1983), pp. 1-14; »The Doer and the Deed: Action as a Basis for Characterization in Narrative», Poetics Today 7 (1986), pp. 20525; »Dispersing/Voiding the Subject. A Narratological Perspective«, Texte 5/6 (1986-7), pp. 180-210; "Introducing and Sustaining Characters in Literary Narrative. A Set of Conditions«, Style 21 (1987), pp. 107-24; »Structuralist Approaches to Character in Narrative. The State of the Art", Semiotica 75 (1989), pp. 1-24; "The What, the When, and the How of Being a Character in Literary Narrative«, Style 24 (1990), pp. 453-68. 
eller dialog, som mit forslag giver grundlag for. ${ }^{2}$ Jeg anbefaler, at travle læsere hurtigt går videre til tredje del.

\section{En minimalistisk definition af litterær karak- ter'}

Eftersom vores fokus her er på karakter og ikke på forskellene mellem litterære og ikke-litterære karakterer, skal jeg ikke i det følgende forsvare en bestemt måde, hvorpå man kan efterspore den litterære/ikke-litterære distinktion, og jeg forventer, at det, jeg siger, vil være kompatibelt med en lang række forskellige synsvinkler på dette kontroversielle emne. Enhver opfattelse, som betragter litteratur som en diskursiv art [species], vil, tror jeg, let kunne relateres til den minimalistiske teori om litterære karakterer. ${ }^{3}$

'Litterær karakter' kan bedst forstås i relation til et mere grundlæggende begreb, nemlig »litterær karakterisering«. Det sidste er en pragmatisk konception i den forstand, at den fokuserer på relationerne mellem tegn og deres brugere. Indenfor denne pragmatiske ramme betragtes litterære karakterer ikke som uafhængige af diskurser eller andre repræsentationer. Karakterer er diskursive produkter, og deres eksistens er fuldstændig afhængig af karakteriseringshandlinger. Sidstnævnte finder dog deres mulighedsbetingelser i den faktiske agens' verden, eftersom en karakterisering grundlæggende er et spørgsmål om, at nogen beskriver, afbilder eller på anden måde betegner noget. Det 'noget', som beskrives, behøver ikke, vil jeg hurtigt tilføje, være mere end et produkt af fantasien, det vil sige indholdet, eller det helt tilsigtede 'objekt' i en repræsentation eller en fiktion, som da Matthew Lewis karakteriserede en satanisk dæmon i The Monk. Lewis eksisterede engang, og hans roman eksisterer stadig, men dæmonen var aldrig mere end et fantasifoster. Selvfølgelig kan en litterær karakterisering i nogle tilfælde referere til noget, der eksisterer (eller engang eksisterede) uden for og før det litterære værk. Det fortærskede eksempel er Napoleon og Tolstojs Krig og fred. Det hjælper at have kendskab til den oprindelige, hvis vi skal forstå den senere, men det er stadig ingen god idé at overføre Tolstojs karakterisering af Napoleon på Napoleon selv. En karakterisering er en repræsen-

2. Jeg har afdækket nogle af disse aspekter $\mathrm{i}$ "Characterization and Fictional Truth in the Cinema«, in David Bordwell \& Noël Coward: Post-Theory. Reconstructing Film Studies, Madison 1996, pp.149-174. Se også min Literature and Rationality. Ideas of Agency in Theory and Fiction, Cambridge 1990. Nogle beslægtede påstande er for nylig blevet forsvaret af Amie Thomasson i Fiction and Metaphysics, Cambridge 1999.

3. For en oversigt over tilgange til emnet, se min »Literature« i Jerrold Levinson (ed.): Oxford Handbook of Aesthetics, Oxford (under udarbejdelse). 
tationshandling, og en litterær karakter er en sådan handlings resultat eller produkt.

Der er en vigtig begrænsning på indholdet af alle de karakteriseringer, som korrekt kan klassificeres som konstitutive for litterære karakterer, nemlig, at de må beskrive eller repræsentere mindst en agent eller samling heraf. 'Agent' - der er essentiel for denne mere begrænsede anvendelse - kan bredt defineres som henvisende til enhver enhed, virkelig eller imaginær, som er i stand til, i det mindste $\mathrm{i}$ ens egen imaginære repræsentation af denne genstand, at udføre en intentionel handling. 'I stand til at udføre en handling', medfører i øvrigt ikke, at genstanden kan repræsenteres eller forestilles som faktisk udførende en specifik gerning. Derimod involverer den en i det mindste momentær handlingskapacitet eller -anlæg. Og intentionel handling kan herefter identificeres som ethvert element af adfærd produceret og orienteret af agentens intention og andre holdninger, så som overbevisning og begær - eller med andre ord nogle (årsagseffektive) mentale holdninger, der betegner den tilstand, som adfærden skal realisere. Jeg vil vende tilbage til sidstnævnte omstændigheder i min gennemgang af indvendinger og modeksempler.

Karakterisering kan dermed defineres minimalt som en tre-punkts relationel begivenhed. I ovennævnte eksempel er hovedelementerne karakteriseringens relation, C, og de tre relata: Matthew Lewis, hans ytring eller diskurs og dets indhold, dæmonen. Hvis vi går ud fra, at karakteriseringen til enhver tid skal udspilles et eller andet sted og på et eller andet tidspunkt eller i en tidsperiode, må vi tilføje en eventuel kompleks rum-tid lokalisering, L, som giver følgende grundlæggende forhold eller begivenhedsstype: <ved L, C, x, y, z >. Denne type begivenhed findes, hvor en eller flere agenter intentionelt beskriver, afbilleder eller repræsenterer nogle agenter $\mathrm{i}$ en enten fiktiv eller non-fiktiv diskurs eller ytring. Der er ikke langt til en definition af en litterær karakterisering, hvis man har en foretrukken måde at skelne mellem litterære og non-litterære diskurser på.

For at opsummere: Hvis en karakterisering skal finde sted som begivenhed eller episode, da må en eller flere faktiske agenter nødvendigvis udføre den rigtige form for figurative eller symbolske handlinger. »Karakter« henviser dermed i denne kontekst til en karakteriserings relevante produkt, det vil sige den afbildede eller repræsenterede agent - ikke agenten per se eller som uafhængig af karakteriseringen, men agenten som afbildet eller repræsenteret i den specifikke karakterisering. De midler, som agenter kan anvende for at udføre karakteriseringshandlinger, er ganske varierede og omfatter elementer såsom fysiske gestikuleringer, verbale ytringer, trykte og audio-visuelle tekster, håndskrevne inskriptioner og så fremdeles. Der er naturligvis karakterer i romaner, men de forekommer ligeledes i japanske 
bunrakudramer, animerede film, hørespil osv. Den grundlæggende definition er meget bred og ubegrænset i den henseende. Den eneste begrænsning er, at de anvendte midler må være sådan, at nogen kan anvende dem intentionelt i forbindelse med afbildning eller beskrivelse af enten en ægte eller imaginær agent.

Begrebet »karakterisering« anvendes ofte til udelukkende at henvise til de repræsentationelle midler, som når nogen klager over, at »romanen var en urimelig karakterisering«. Men den sidstnævnte brug er i al væsentlighed at forstå som resultatet af mangel på et mere præcist udryk, for medmindre en agent har gjort noget med den rigtige form for intention, kan der ikke udføres en karakterisering af nogen og derfor er der heller ingen karakterer. Dette er i øvrigt ikke det samme som (ukorrekt) at påstå, at karakterer altid har alle - eller kun - de betydninger deres skabere tildelte dem. Pointen er først og fremmest pragmatisk, motiveret af minimalistens aversion mod en bestemt form for reifikation. Hvis vindene og bølgerne på en eller anden måde havde skabt revner i klipperne, der kunne læses som »Mis med de blå øjne gik op ad bakke og ned ad bakke og op... osv«, ville dette ikke være et fragment af en karakterisering. Det kunne være højst interessant og endda underholdende at læse, men vores litterære begreber ville kun kunne anvendes på dette unormale naturfænomen på en udvidet metaforisk måde. Og selvom nogen vil mene, at f.eks. Charles Dickens' karakterisering af Scrooge beskriver et faktisk familiemedlems væsentlige egenskaber rammende, så er Dickens' novelle, hvori den berygtede gnier og jule-hader forekommer, ikke en karakterisering af denne faktiske person, på samme måde som den egentlige person ikke er en karakter i Dickens historie. At hævde, at en onkel eller en anden person er »en Scrooge» kan være træffende, men en sådan bemærkning er ikke korrekt forstået, hvis den betragtes som en påstand om indholdet af novellen. På samme måde som minimalisten insisterer på, at karakteriseringer er intentionelt gennemførte handlinger, og dermed blokerer for en række abstrakte overførelser og tværkategoriseringer, insisterer minimalisten også på at afgrænse karaktererne i forhold til deres relevante karakteriseringer. Pointen er den, at intentionelt producerede kulturartefakter, så som tekster, er karakteriseringer, og at karakterer - i den forståelse de her har - kun eksisterer i kraft af sådanne karakteriseringer. Er man ikke opmærksom på denne sidste pointe, føres man væk fra minimalistens sti og op ad vejen mod landet for forskellige oppustede metafysikker for karakterer, hvor spørgsmålet er, hvilken væremåde, eksistens, subsistens etc. fiktionens skabninger rummer. Har Scrooge, som abstrakt type, været til stede hele tiden? Er han, sammen med Molières gnier og alle de andre grådige personer i litteraturen (Scrooges fortid, nutid og fremtid), blot momentane eksemplificeringer af en arketype eller en funktion? Dette er vanskelige 
spørgsmål, som måske ikke har nogle egentlige svar. Minimalisten vil kun insistere på, at Dickens engagerede sig i en karakterisering og skabte en historie, som indeholdt en karakter i den forståelse af begrebet, som der argumenteres for her. Minimalisten vil modsætte sig enhver fristelse til at uddrage sidstnævnte fra karakteriseringen, selvom der, så længe denne kendsgerning bliver respekteret, naturligvis kan foretages forskellige interesse-relative klassifikationer og sammenligninger. ${ }^{4}$ Jeg kan spørge, hvordan en givet litterær gnier adskiller sig fra andre, som tilhører en mere almindelig type. Men det, jeg gerne vil modsætte mig, er tanken om, at der bogstaveligt eksisterer en Scrooge, som kan løsrives fra Dickens' værk og overføres til andre værker, hvor han på den ene eller anden måde bliver fortsat, forandret, omdannet etc. Naturligvis er der en tilsyneladende uendelig række adaptioner og biprodukter af A Christmas Carol (ligesom der findes en kulturhistorie om Don Juan-relaterede figurer og James Bond-typer), men i minimalistens forståelse af karakteren, er der ingen forpligtelse over for eksistensen af en selvidentisk, værkuafhængig arketype eller person, som overskrider disse forskelligartede operationer.

\section{Kort oversigt over udfordringer til det minima- listiske forslag}

Potentielle indvendinger og modeksempler mod minimalistens forslag kan placeres under følgende nøglebegrebslige punkter:

Den repræsentationelle betingelse: findes der ingen ikke-repræsentationelle litterære karakterer?

Den intentionelle betingelse: findes der ikke ikke-intentionelle karakteriseringer?

Den agentielle betingelse: skal en karakterisering afbilde en agent, og skal en karakter på en eller anden måde være agent?

Anvendelsen af den agentielle betingelse: skal agentstatus kræve kapacitet til at deltage $\mathrm{i}$ attitudeorienterede handlinger? Er der ingen rivaliserende agentbegreber?

4. Ideen om 'interesse-relativitet' har jeg fra Peter Lamarques "How to Create a Fictional Character", in Paisley Livingston \& Berys Gaut (eds.): The Creation of Art. New Essays in Philosophical Aesthetics, New York 2002. Lamarque gør ikke de same pointer vedrørende metafysik, men han kontrasterer på en givende made metafysik og korrekte litterære perspektiver på karakteren. 
Logisk set ville modeksempler og indvendinger vendt mod disse punkter være udfordringer til nødvendigheden af forslagets mange klausuler. Man kunne naturligvis også spørge, om disse klausuler holdt sammen overhovedet er tilstrækkelige som en analyse af karakter. Eller sagt med andre ord, kunne en litterær diskurs opfylde disse krav og samtidig undlade at være en karakterisering? Og hvilke andre umeddelte krav skulle tilfredsstilles? Hvis sidstnævnte krav skulle skæres ud i pap, ville den deraf følgende teori så stadigvæk være minimalistisk?

Da jeg ikke kan forstille mig, at $K \& K$ s læsere ville synes, at en systematisk analyse af disse punkter er videre stimulerende, vil jeg i det følgende være selektiv og fokusere på de indvendinger, som måske er mest interessante at diskutere; og det med udgangspunkt i en meget generel indsigelse, der angår en del af de specificerede punkter. $\mathrm{Og}$ eftersom det hele handler om karakterer, hvorfor så ikke videregive replikkerne til nogle dramatis personae?

\section{Dialektik (fragment)}

Antitese (arrogant, med et strejf af utålmodighed og irritation)

Min kære, stædige Hr. Tese. Selvom du fremstiller dig selv som en moderat sjæl ivrig efter at undgå kraftige metafysiske fordringer i din jagt efter et klogt, minimalistisk begreb, vil du rent faktisk have os til at acceptere et bundt metafysiske påstande - i virkeligheden en håbløs ideologi - for hvilke du ikke har fremlagt så meget som skyggen af et argument. Dette bundt inkluderer intet mindre end en uklar teori om frihed, gammeldags humanistiske ideer om individuel handling og autonomi, og de sædvanlige a-historiske præmisser omkring en række problematiske begreber. Hvorfor, om jeg tør spørge, skal alle litterære karakterer være i stand til at handle, og hvorfor, selvom dette var tilfældet, vil disse handlinger nødvendigvis være forbundet til dybdepsykologiske termer af alskens slags - såsom jeres amerikanske pølsesnak om psykologiske attituder? Er der ingen behavioristisk fortællinger, eller endnu bedre, ingen deterministiske romaner? Har du glemt Butor, Sollers, Robbe-Grillet, Sukenick, Federman, Barth, le nouveau roman? Eller hvad med Becketts senere fragmenter? For ikke at nævne de diverse asiatiske diskurser renset for dine vestlige oplysningsfortællinger om individets bedrifter? 
Nuvel, min forudsigelige og fordringsfulde antitese, det er rigtigt nok, at den minimalistiske position $\mathrm{i}$ en vis forstand fordrer en metafysik. Men spørgsmålet er, om der er noget galt med det standpunkt, eller med hvad end det måtte være du gerne ser, vi i stedet tilslutter os. Bemærk at det minimalistiske forslag er motiveret af det formål at bryde med den lange tradition, som antager, at egenskaber (inklusiv karaktertræk, kvaliteter osv.) er abstrakte enheder eller typer, som hverken kan skabes eller destrueres, som 'altid allerede' er der, så at sige, og hvor alle mulige kombinationer af dem også på en måde allerede eksisterer, så karakterer - litterære eller andre, fiktive eller ikke - ikke kan skabes i dette ords egentlige betydning. Du bryder dig med sikkerhed ikke om den slags platonisk metafysik, hvorfor du, i hvert fald i den henseende, burde have sympati med mig. Min insisteren på karakteriseringens handlinger fører os tilbage til den tegnskabende praksis, som blev anvendt i den faktiske historiske kontekst. (Husk nu på at »altid historisere!« selv er et universalt påbud og ikke kun et midlertidigt råd.) Jeg har ikke argumenteret for en metafysisk frihed (efter enten 'kompatibilistiske' eller 'inkompatibilistiske' linier, hvor førstnævnte accepterer determinisme og dog finder plads til en form for frihed), for det var ikke målet med at belyse et minimalistisk karakterbegreb. Rent faktisk vil jeg forblive neutral hvad angår disse gamle metafysiske stridigheder. Det minimalistiske begreb, påstår jeg, er den størrelse, der harmonerer med en fornuftig litteraturkritisk praksis. Det er den, vi ikke kan klare os foruden, og om det er sandt i den metafysiske realists forstand, er en anden sag, hvorom den mest forsigtige linje er agnosticisme. Den vigtigste motivation for forslaget er en række kendsgerninger om vores kritiske idiom, hvilket vil sige kritiske diskurs i et bredt udvalg af kontekster. Vi vil alle gerne karakterisere Hamlet som en karakter i Shakespeares stykke. Men Hamlet, Prins af Danmark-og her refererer jeg til det, vi genkender som stykkets titel - er ikke en karakter i stykket. Hamlets »At være eller ikke-være«-monolog er heller ikke nogen karakter i stykket, og det samme gælder for den række begivenheder, som er kendt som 'musefælden'. Gymnasieelever, som vil klassificere musefældescenen som en karakter, vil blive rettet af deres lærer og det med god grund. Det er nemt at skitsere en ikke-kontroversiel liste over stykkets karakterer, og denne form for kritisk kompetence er den ultimative base for forslaget, der optager denne slags data og leder efter deres grundsættende basis. Så med mindre du rykker for en form for global skepticisme, er det rigtige spørgsmål, om vi kan fortsætte derfra for at behandle vanskeligere og mere gådefulde tilfælde ved at spørge efter, om der er nogle ægte modeksempler til denne måde at belyse karakterbegrebet på. 
Med hensyn til kerneklausulen angående elementets handlingskapacitet, defineret som adfærd orienteret af attituder, er dette ikke et spørgsmål om at importere en snæversynet psykologisk doktrin (fejlagtigt taget for at være en form for amerikansk egopsykologi), men en filosofisk gentagelse af de blotte minimale betingelser for hvad som helst, der overhovedet fortjener at blive anerkendt som psykologi. Freud, og så vidt jeg kan se også Lacan, giver begge mulighed for, at den individuelle psyke inkluderer ego og dets følelser og bestræbelser, selv når de fremhæver den vigtige pointe, at ikke alt i psyken er et spørgsmål om bevidsthed, opmærksomhed og overvejelse. Men du fanger ikke den tragiske ironi (dissoi logoi), medmindre du har en dobbelt diskurs, hvori agenten er afbildet både som en aktiv, stræbende figur og som en marionet for Nødvendigheden (ananke, skæbne etc.).

Husk nu på at i en forestillet eller fiktionel kontekst kan næsten hvad som helst blive forestillet som et i det mindste momentært erfaringssubjekt, i stand til at udføre i det mindste nogle basale mentale handlinger, så som at forsøge at huske noget eller kæmpe for at tænke på noget eller brydes med en fornemmelse eller følelse. Tanken er 'blot', at en eller anden mental tilstand, som både kan være bevidst eller ubevidst, men som kræver et intentionelt objekt, et propositionelt indhold, eller en oplevet kvalitet eller fænomenologisk tilsyneladenhed, genererer eller fører til et andet mentalt stadie, hvor denne minimale forbindelse eller sekvens er kompatibel med, men ikke logisk reducerbar til, en fysisk eller anden type årsagssammenhæng. Noget må på et eller andet tidspunkt føle, tænke, registrere, opfatte, bemærke og, i behovet for noget andet, prøve at gøre noget - også selvom det kun er et spørgsmål om at prøve at huske noget eller at tænke på noget andet. Tilstanden har dermed intet at gøre med at være en person i henhold til en eller anden filosofs normative model herfor, da alle sådanne modeller vægter komplekse krav om enheden i store samlinger af sådanne mentale stadier og udfald. Det minimale karakterbegreb kræver heller ikke, at prøvelserne og følelserne tilsammen udgør et system, som kvalificerer sig til at blive kaldt klogt eller rationelt i nogen form for vurderingshenseende. For at underbygge denne pointe med et eksempel så lad mig nøjes med at nævne, at det psykologiske vrag afbildet i Becketts stykke Krapps sidste bånd tydeligvis ikke lever op til forskellige normer for rationalitet og personlighed, men fuldt ud lever op til det minimalistiske karakterbegreb.

Det forekommer mig, at grunden til, at nogle teoretikere undviger et agens-baseret karakterbegreb, er, at de reagerer negativt på en antaget model, hvor et normativt paradigme for, hvad det vil sige at være være et subjekt eller person, er opstillet som en standard, mod hvilke alle litterære karakteriseringer skal måles. Man kan rigtig nok finde denne anskuelse i litteraturen, men ligeledes en del velartikuleret kritik af den, så som Thomas 
Dochertys bog Reading (Absent) Character. ${ }^{5}$ Jeg er enig med kritikken af den gammeldags mimetiske model, men ikke med drejningen hen imod forskellige ekstremistiske anti-humanismer. Docherty synes i øvrigt at gøre en heideggeriansk konception af Dasein grundlæggende for definitionen af karakter, hvilket kunne se ud til at implicere accept af den noget tvivlsomme idé, at Heideggers 'antropologi' skitserer selve essensen af litterær agens. Min egen påstand omkring nødvendigheden af episoder af oplevet kvalitet, stræben eller mental handling er, tror jeg, mindre snæver. Her gentager jeg i øvrigt den pointe, som Mette Hjort vellykket forfølger i sin bog The Strategy of Letters: ingen strategier uden strateger.

En større udfordring i denne forbindelse er spørgsmålet, om der ikke kunne eksistere en fuldstændig deterministisk, radikalt a-psykologisk fiktion. I første omgang er jeg tilbøjelig til at svare, at det selvfølgelig er muligt, men at en sådan slags historie - hvis det overhovedet er en - ikke har nogen karakterer. Det var ikke en del af den minimalistiske tilgang at fordre, at alle litterære værker har karakterer. Men selv dette spørgsmål er mere spidsfindigt, end det umiddelbart ser ud til, da vi må gå et skridt videre og spørge om 1) en fortæller ikke kan fungere som en karakter (på denne bestemte måde) og 2) om alle (narrative) litterære værker ikke i det mindste har en implicit fortæller og således, forudsat et positivt svar til 1), en karakter. Jeg skal ikke prøve at vurdere denne form for argument her. Vi kan under alle omstændigheder stadig spørge til fiktioner, som udforsker radikalt divergerende karakterbegreber, ved at spørge, om nogen af disse burde forstås som indeholdende karakterer, samtidig med at de er ude af stand til at opfylde de minimalistiske betingelser. De store 19. og 20. århundredes-naturalister passer ikke ind her, da de, både på et eksplicit og implicit niveau, kræver, at vi forestiller os at Jacques, Clyde og Julies kropslige bevægelser er determineret af blinde, dybt upersonlige og a-rationelle årsager, men også at disse væsner prøver at gøre både det ene og det andet, imens de mildest talt kæmper for at opnå en forståelse for, hvad det er der sker med dem, hvilket igen kategoriseres som en slags mental handling (og dermed tilfredsstiller den minimalistiske betingelse). Så snart en episodisk følelsesladet bevidsthedstilstand eller begivenhed reagerer, observerer, er tilstedeværende eller stræber, opfyldes de minimale betingelser. ${ }^{6}$ Hvis noget sådan ikke er tilstede i et bestemt litterært værk, hvilket meget vel kunne være tilfældet, havde vi

5. For det gamle mimetiske synspunkt, se W. J. Harvey: Character and the Novel, London 1965. For sin åndrige afvisning i lyset af eksperimenterende prosa og post-strukturalistisk litteraturteori, se Thomas Dochertys vigtige bog: Reading (Absent) Character. Towards a Theory of Characterization in Fiction, Oxford 1983. For fremhævelsen af Dasein som en 'series of fleeting and deferred instantiations of subjectivity' se p. 230 . 
ikke nogen grund til at tale om karakterer her, men kun om deres noget bemærkelsesværdige fravær.

Afslutningsvis synes jeg det er værd at understrege, at ifølge den minimale opfattelse skitseret ovenfor, er det ikke sagt, at alle karakterer er "individer', forstået som partikulære levende organismer. Definitionen omfatter kollektive agenter såvel som en hel række af animistiske og overnaturlige fremstillinger, rækkende fra Poes »House of Usher«til»The Ghost of Christmas Past, Present, and Future

Et meget svært problem, der ikke blev nævnt af antitesen, ligger i at fortsætte med at udskille og identificere karakterer inden for et bestemt værk eller forfatterskab. Er Becketts Krapp en karakter eller flere? Selvom vi er fristede til at sige det første, er der intet i minimalistens koncept, der kræver dette svar. Man kunne også sige, at der er en krop, der fra det ene øjeblik til det andet fremstiller forskellige karakterfaser eller fragmenter. Fortællinger om personlighedsspaltning komplicerer sagen yderligere. Et andet beslægtet spørgsmål er følgende: kan ‘den samme' karakter optræde i en serie af romaner af en enkelt forfatter? For eksempel: er det den samme Lantier, Zola skriver om mange år efter en tidligere karakterisering, hvor denne titel anvendes, eller er det en ny og anderledes karakter? Under hvilke betingelser ville denne form for identitet bestå eller bryde sammen? En mulighed her ville være at anvende Kripkes idé om navne som rigide designatorer og spørge om, de relevante skabere havde til hensigt, at læsere skulle forestille sig en sådan rigiditet anvendt: kun i tilfælde af, at svaret er bekræftende, har vi én karakter og dens metamorfoser. Dette er i det mindste en simpel hypotese, der er værd at teste.

\section{Antitese (kedsommelig og ukomfortabel)}

Jeg synes stadig, at meget af dette er højst problematisk, men vil skifte til en anden problemstilling. Hvad er pointen med dit minimalistiske forslag? Hvad ville konsekvenserne være, hvis vi accepterede det?

Tese

Hvis man går ud fra den minimale karakterkonception, kunne forskningen fokuseres omkring nærtbeslægtede spørgsmål, så som dens basis og implikationer, såvel som på en række interessante karakterologiske spørgsmål, som

6. Jeg lader her en række forhold som berører bevidsthedsfilosofi stå åbne. For baggrund, se George M. Wilson: The Intentionality of Human Action, Stanford 1989, og Paul M. Pietroski: Causing Actions, Oxford 2000; en bred vifte af synspunkter er præsenteret i Shaun Gallagher og Jonathan Shear (eds.): Models of the Self, Thorverton 1999. 
den kun ville tjene som baggrundspræmis for. F.eks. de svære og uløste spørgsmål som relationen til individuationen lige har rejst. Der er, som du helt sikkert ved, mange fascinerende karakterrelaterede problemer - historiske så vel som begrebsmæssige - som fremtidens litterære forskning kan fokusere på.

Oversat af Marianne Wolff Lundholt 